\title{
Porta Hepatis Lymph Node
}

National Cancer Institute

\section{Source}

National Cancer Institute. Porta Hepatis Lymph Node. NCI Thesaurus. Code C117871.

A lymph node located in the transverse fissure of the liver. 